\title{
EFEKTIFITAS PENGGUNAAN B AHASA LEMBAK DALAM PENYAMPAIAN MATERI PELAJARAN OLEH GURU PADA SISWA KELAS VII SMP NEGERI 1 TANJUNG TERDANA BENGKULU TENGAH
}

\section{Oleh :}

\author{
D A H L I A
}

\section{S2 Ilmu Komunikasi Fakultas Ilmu Sosial dan Ilmu Politik Universitas Bengkulu}

\begin{abstract}
The problem of this study is how the effectiveness of the use of the Lembak language in the delivery of subject matter by teachers to Class VII Students of Tanjung Tanjung State Junior High School Terdana Bengkulu Tengah. The purpose of this study was to find out in detail the effectiveness of the use of Lembak language in the delivery of subject matter by teachers to Grade VII Students of SMP Negeri 1 Tanjung Terdana Bengkulu Tengah, this study used a descriptive method using a quantitative approach. The population in this study were students in grade VII Tanjung 1 State Middle School There were 117 people in Central Bengkulu. In this study the sample was taken as much as $25 \%$ of the population so that the sample amounted to 29 people. Data collection techniques in this study used observation, questionnaire, and documentation techniques. Data analysis techniques were carried out with the help of interpretation based on percentage calculation (proportion interpretation) and using the help of the Likert Scale. The results of the study show an explanation of the subject matter delivered by the teacher through the Lembak language to students in grade VII of Tanjung 1 Middle School SMP Menghana Bengkulu Tengah can be said to be effective. This is based on the results of the average score of 59.59 if consulted with the Likert scale used, the score is in the interval 51-62 in the effective category. The use of Lembak language by the teacher according to respondents can influence the achievement of learning objectives, the subject matter can be understood by students, the material is mastered by students, students have better learning outcomes and students are motivated to learn.
\end{abstract}

\section{Keywords: Effectivennes, Lembak Language, Students of SMP Negeri 1 Tanjung Terdana}

\section{PENDAHULUAN}

Bangsa indonesia merupakan bangsa yang majemuk. Bangsa ini terdiri dari bermacam suku bangsa.Demikian pula setiap sukunya memiliki bahasa daerah sendiri.Adanya mobilitas antar masyarakat menyebabkan terjadinya pencampuran bahasa yang diakibatkan kontak dari individu-individu yang berasal dari daerah berbeda. Komunikasi yang terjadi saling menyesuaikan satu sama lainnya. Dwibahasa atau penggunaan dua bahasa bukan hal yang sulit ditemukan dalam komunikasi.
Penggunaan dua bahasa merupakan ketermapilan khusus. Tujuannya adalah mencapai efektifitas pembicaraan. Penggunaan dua bahasa akan memungkinkan pembicaraan berlangsung menarik dan interaksi penutur dan pendengar dapat berlangsung menarik komunitatif. Penggunaan kode (bahasan asing/daerah) dalam komunikasi berarti memasukkan istilah-istilah lain dari bahasa yang dipergunakan. Penggunaan kode melalui proses alih kode dan campur kode dapat memberikan dampak positif terhadap kelangsungan komunikasi. Dengan penggunaan alih kode dan campur 
kode maka diharapkan komunikasi antara dua pihak atau lebih dapat berjalan efektif.Di samping itu, penggunaan alih kode dan campur kode dapat pula membuat pembicaraan lebih menarik.

Hanya saja dalam tataran penggunaan bahasa Indonesia yang baik dan benar, penggunaan kode dapat dikatakan menyalahi kaidah. Penggunaan kode-kode tertentu, baik yang diambil dari bahasa daerah maupun bahasa asing, membuat si penutur sulit secara konsisten menggunakan bahasa indonesia yang baik dan benar.

Penggunaan dua bahasa ini sering kali temui dalam kehidupan sehari-hari. Demikian hanya dalam dunia pendidikan. Bahasa indonesia dipergunakan sebagai bahasa pengantar dalam komunikasi di lingkungan sekolah dan dalam proses berlajar mengajar. Seperti halnya di Bengkulu Tengah yang dihuni oleh beragam masyarakat yang memiliki bahasa daerah asal masing-masing. Bahasa-bahasa daerah yang akrab didengar masyarakat Bengkulu Tengah di antaranya bahasa Lembak, bahasa Rejang, bahasa Serawai, bahasa Mulak Bintuhan, bahasa Melayu Bengkulu, dan bahasa Pasemah, bahasa Minang, bahasa Jawa, dan sebagainya. Bahasa-bahasa daerah tersebut sering digunakan secara bergantian dengan bahasa Indonesia sebagai bahasa formal.

Banyaknya bahasa daerah ini tidak membatasi komunikasi antarmasyarakat. Terjadinya komunikasi penduduk merupakan faktor penting terjadinya pencampuran bahasa untuk mempelancar proses komunikasi. Hal ini pula yang mendorong di antara masyarakat dapat menguasai lebih dari dua bahasa.

Kenyataan di lapangan seperti Bengkulu Tengah, khususnya pada siswa Kelas VII SMP Negeri 1 Tanjung Terdana, penggunaan bahasa daerah masih sering dipergunakan dalam proses belajar mengajar. Berdasarkan hasil prapenelitian di sekolah pada tanggal 02 Februari 2013, dikemukakan oleh salah satu seorang guru
SMP Negeri 1 Tanjung Terdana Bengkulu Tengah yang cukup banyak berasal dari suku Lembak.

Berdasarkan uraian latar belakang di atas maka peneliti tertarik untuk melakukan penelitian lebih lanjut melalui judul penelitian Efektifitas Penggunaan Bahasa Lembak Dalam Penyampaian Materi Pelajaran Oleh Guru Pada Siswa Kelas VII SMP Negeri 1 Tanjung Terdana Bengkulu Tengah.

\section{METODE PENELITIAN}

Penelitian ini menggunakan metode penelitian deskriptif. Penelitian deskriptif dimaksudkan untuk menjelaskan/mengambarkan variabel masa lalu dan sekarang (sedang terjadi), (to describe $=$ menggambarkan atau membeberkan (Arikunto, 2006:10). Di dalamnya terdapat upaya mengambarkan, mencatat, analisis dan menginterpretasikan kondisi-kondisi yang sekarang terjadi. Data yang digunakan adalah data yang berbentuk kuantitatif. Penelitian kuantitatif menyajikan data dalam bentuk deskripsi dengan menggunakan informasi angkaangka statistik. Sesuai dengan penjelasan tersebut maka maksud penelitian ini adalah mengetahui efektifitas penggunaan bahasa Lembak dalam penyampaian materi pelajaran oleh guru di SMP Negeri 1 Tanjung Terdana Bengkulu Tengah.

\section{Populasi dan Sampel Penelitian}

Menurut Arikunto (2006: 108) populasi adalah keseluruhan subjek penelitian.Maka populasi dalam penelitian ini adalah seluruh siswa pada VII SMP Negeri 1 Tanjung Terdana Bengkulu Tengah. Berdasarkan data tabel di atas, diketahui populasi penelitian ini berjumlah 117 orang siswa yang dibagi dalam 3 kelas. Penentuan jumlah sampel dalam penelitian ini berdasarkan pada pendapat Arikunto (2006:112), bahwa apabila populasi lebih dari 100 orang maka sampel dapat diambil $10-15 \%$ atau $20-25 \%$. Dalam penelitian ini sampel diambil 
sebanyak $25 \%$ dari populasi yang ada, sehingga sampel yang diteliti adalah sebagai berikut: Berdasarkan perhitungan di atas, maka sampel dalam penelitian ini berjumlah 29 siswa. Untuk mengambil masing-masing siswa yang menjadi perwakilan populasi untuk setiap kelasnya ditentukan melalui teknik acak (random sampling) dengan menggunakan penomoran pada masing-masing siswa, kemudian nomor tersebut diambil secara acak sebanyak jumlah sampel untuk menentukan siap yang akan menjadi sampel penelitian.

\section{Teknik Pengumpulan Data}

Pada penelitian ini teknik yang digunakan untuk mendapatkan data adalah:

a. Kuesioner

Kuesioner adalah jumlah pertanyaan tertulis yang digunakan untuk memperoleh informasi dari responden dalam arti laporan tentang pribadinya atau hal-hal yang ia ketahui (Arikunto, 2006:151). Dalam penelitian ini kuesioner digunakan sebagai alat pengumpulan data yang pokok.Dilakukan dengan menyebarkan kuesioner kepada siswa kelas VII yang ditetapkan menjadi sampel penelitian ini.Kuesioner ini berisikan pertanyaan yang menjadi fokus penelitin ini.

b. Observasi

Observasi yakni memperhatikan sesuatu dengan mata, atau memerhatikan terhadap suatu objek pengamatan dengan menggunakan seluruh alat indera (Arikunto, 2006:156).Pengmatan ini dimaksudkan agar penulis dapat melihat dan mengetahui kenyataan yang terjadi di dalam objek penelitian.

\section{c. Dokumentasi}

Dokumentasi merupakan metode pengumpulan data dengan memperlajari barang-barang tertulis seperti buku, majalah, dokumen, peraturan-peraturan, notulen rapat, catatan harian dan sebagainya (Arikunto, 2006:158).Data yang dibutuhkan dalam penelitian ini seperti data keadaan tenaga pengajar, staf Tata Usaha dan siswa.

\section{Teknik Analisis Data}

Setelah data diperoleh akan dilakukan analisis data. Analisis data akan diolah secara sistematis. Dalam menganalisis data, penelitian ini menggunakan metode deskriptif kuantitatif. Langkah-langkah analisis dapat dilakukan dengan bantuan analisis sebagai berikut:

Penggunaan Tabel Distribusi
Frekuensi

Bantuan tabukasi distribusi frekuensi berupa susunan data dalam suatu tabel yang telah diklasifikasikan menurut kelas atau kategori tertentu.Klasifikasi atau ini berupa tingkatan alternatif jawaban yang dapat dipilih oleh responden. Dalam penelitian ini, kriteria pengukuran menggunakan bantuan penafsiran berdasarkan penghitungan prosentase (penafsiran proposi) sebagai berikut:

$$
\begin{aligned}
& \mathrm{S}=\text { Presentase yang akan dicari } \\
& \mathrm{R}=\text { Skor perolehan } \\
& \mathrm{N}=\text { Skor tertinggi yang } \\
& \text { diharapkan }
\end{aligned}
$$

Tingkat persentase jawaban responden akan dilihat dari pengelompokkan semua data yang diperoleh. Data tersebut akan disusun dalam tabulasi distribusi frekuensi, susunan data dalam tabel yang telah diklasifikasikan menurut kelas atau kategori tertentu. Kemudia data tersebut diberi penjelasan dan penafsiran.

$\begin{array}{lr}\text { b. } & \begin{array}{l}\text { Penggunaan Skala Distribusi } \\ \text { Bergolong }\end{array} \\ \text { Bagaimana } & \text { efektifitas } \\ \text { penggunaan bahasa Lembak dalam } & \text { Lembampaian materi pelajaran materi }\end{array}$


pelajaran oleh guru di SMP Negeri 1 Tanjung Terdana Bengkulu Tengah akan diukur dengan menggunakan bantuan skala Likert. Menurut Sugiyono (2009:93) skala Likert digunakan untuk mengukur sikap, pendapat dan persepsi seseorang atau sekolompok orang tentang fenenomena sosial.

Untuk memudahkan pengukuran, setiap item pertanyaan maka diberi skor. Kriteria pengukuran dalam penelitian ini ditentukan dari jawaban pertanyaan dengan skor nilai:

- Jawaban alternatif a diberi skor 5

- Jawaban alternatif b diberi skor 4

- Jawaban alternatif c diberi skor 3

- Jawaban alternatif d diberi skor 2

- Jawaban alternatif e diberi skor 1

Perolehan skor dari jawaban responden dijumlahkan dari yang paling rendah sampai yang paling tinggi. Jumlah tersebut akan disusun skala interval dengan menggunakan rumus sebagai berikut:

I melambangkan interval (jarak dalam satu kategori/kelas) yang digunakan untuk mengelompokkan masing-masing skor yang diperoleh oleh setiap jawaban responden.skala interval ini adalah terdiri dari 15 pertanyaan dimana setiap pertanyaan terdiri dari 5 pilihan skor, berarti nilai tertinggi adalah $5 \times 15=75$ dan terendah 1 X $15=15$, sehingga efektifitas penggunaan bahasa Lembak dalam penyampaian materi pelajaran oleh guru di SMP Negeri 1 Tanjung Terdana Bengkulu Tengah adalah:

- Sangat efektif apabila skor jawaban mencapai 63-75

- Efektif apabila skor jawaban mencapai 51-62

- Sedang apabila skor jawaban mencapai 39-50

- Kurang efektif apabila skor jawaban mencapai 27-38

- Tidak efektif apabila skor jawaban mencapai 15-26

\section{HASIL PENELITIAN DAN \\ PEMBAHASAN \\ Tercapainya Tujuan Pembelajaran}

Tentang percapainya tujuan pembelajaran melalui penggunaan bahasa Lembak oleh guru dalam menjelaskan pelajaran di kelas, akan diukur melalui 3 item pertanyaan. Berikut hasil masingmasing item sesuai jawaban yang diberikan oleh 29 orang responden yang diteliti.

Berdasarkan data tabel 5.3 (terlampir), diketahui bahwa sebanyak 13 orang atau sebesar $44,83 \%$ responden menyatakan penjelasan yang disampaikan guru melalui penggunaan bahasa Lembak selalu sesuai dengan tujuan pembelajaran. Sebanyak 11 orang atau sebesar 37,93\% responden menyatakan sering, dan 3 orang atau sebesar $10.34 \%$ responden menyatakan kadang-kadang. Sementara itu hanya terdapat 2 siswa atau $6,89 \%$ responden yang menyatakan penjelasan yang disampaikan guru melalui penggunaan bahasa Lembak jarang sesuai dengan tujuan pembelajaran. Tidak terdapat responden yang menyatakan bahwa penjelasan yang disampaikan guru melalui penggunaan bahasa Lembak tidak pernah sesuai dengan tujuan pembelajaran.

Sesuai dengan data tabel 5.4 (terlampir), diketahui bahwa sebanyak 7 orang atau sebesar $24,14 \%$ responden menyatakan siswa selalu mengetahui tujuan pembelajaran setelah mendengarkan penjelasan guru melalui penggunaan bahasa Lembak. Sebanyak 8 orang atau sebesar $27,59 \%$ responden menyatakan sering, 11 orang atau sebesar 37,93\% responden menyatakan kadang-kadang, dan 3 orang atau 10,34\% yang menyatakan jarang mengetahui tujuan pembelajaran setelah mendengar penjelasan guru melalui penggunaan bahasa Lembak. Sementara itu tidak terdapat siswa atau responden yang menyatakan tidak pernah mengetahui tujuan pembelajaran setelah mendengarkan penjelasan guru melalui penggunaan bahasa Lembak 
Berdasarkan data tabel 5.5 (terlampir), diketahui bahwa sebanyak 13 orang atau sebesar $44,83 \%$ respoden menyatakan tujuan pembelajaran selalu tercapai dengan penjelasan guru mulai penggunaan bahasa Lembak. Sebanyak 14 orang atau sebesar $48,27 \%$ responden menyatakan sering, dan 2 orang atau sebesar $6,89 \%$ responden menyatakan kadang-kadang. Sementara itu tidak terdapat responden yang menyatakan tujuan pembelajaran jarang ataupun tidak pernah tercapai dengan penjelasan guru melalui penggunaan bahasa Lembak.

\section{Hasil Jawaban Responden tentang Materi Pelajaran Dapat Dipahami Siswa}

Berdasarkan data tabel 5.6 (terlampir), diketahui bahwa sebanyak 7 orang atau sebesar 24,14\% responden menyatakan melalui penggunaan bahasa Lembak, siswa selalu memahami isi pelajaran, sebanyak 17 orang atau sebesar 58,62\% responden menyatakan sering, sebanyak 4 orang atau sebesar $13,79 \%$ yang menyatakan kadangkadang, dan hanya 1 orang atau 3,45\% yang menyatakan jarang. Sementara itu tidak terdapat siswa atau responden yang menyatakan melalui penggunaan bahasa Lembak, siswa tidak pernah memahami isi pelajaran.

Sesuai dengan data tabel 5.7 (terlampir), diketahui bahwa sebanyak 9 orang atau sebesar $31,03 \%$ responden menyatakan dengan penjelasan yang disampaikan guru melalui penggunaan bahasa Lembak siswa selalu mengetahui makna yang diajarkan. Sebanyak 7 orang atau sebesar $24,14 \%$ responden menyatakan sering, sebanyak 11 orang atau sebesar 37,93\% responden menyatakan kadang-kadang, dan 2 orang atau sebesar $6,89 \%$ menyatakan jarang. Dari seluruh responden yang diteliti, tidak terdapat siswa atau responden yang menyatan dengan penjelasan yang disampaikan guru melalui penggunaan bahasa Lembak siswa tidak pernah mengetahui makna yang diajarkan.
Berdasarkan data tabel 5.8 (terlampir), diketahui bahwa sebanyak 8 orang atau sebesar $27,59 \%$ responden menyatakan melalui penggunaan bahasa Lembak siswa selalu merasa perlajaran lebih mudah dipelajarai. Sebanyak 11 orang atau sebesar $37,93 \%$ responden menyatakan sering, dan sebanyak 10 orang atau sebesar $34,48 \%$ responden menyatakan kadangkadang. Sementara itu tidak terdapat siswa atau responden yang menyatakan melalui penggunaan bahasa Lembak jarang ataupun tidak pernah merasa pelajaran lebih mudah dipelajari.

\section{Hasil Jawaban Responden tentang Materi Dikuasai Siswa}

Berdasarkan data tabel 5.10 (terlampir), diketahui bahwa sebanyak 6 orang atau sebesar $20,69 \%$ responden menyatakan dengan penjelasan yang disampaikan guru melalui pengginaan bahasa Lembak siswa selalu dapat menerapkan apa yang disampaikan guru. Sebanyak 15 orang atau sebesar 51,72\% responden menyatakan sering, sebanyak 4 orang atau sebesar $13,78 \%$ responden menyatakan jarang. Sementara itu tidak terdapat siswa atau responden yang menyatakan penjelasan yang disampaikan guru melalui penggunaan bahasa Lembak siswa tidak pernah dapat menerapkan apa yang disampaikan guru.

Sesuai dengan data tabel 5.11 (terlampir), diketahui bahwa sebanyak 12 orang atau sebesar $41,38 \%$ responden menyatakan dengan penjelasan yang disampaikan guru melalui penggunaan bahasa Lembak siswa selalu merasa penguasaan baha yang sulit menjadi lebih mudah. Sebanyak 9 orang atau sebesar $31,03 \%$ responden menyatakan sering, sebanyak 7 orang sebesar 24,14\% responden menyatakan kadang-kadang, dan 1 orang atau $3,45 \%$ menyatakan jarang. Sementara itu tidak terdapat siswa atau responden yang menyatakan dengan penjelasan yang disampaikan guru melalui penggunaan bahas Lembak siswa tidak 
pernah merasa penguasaan bahan yang sulit menjadi lebih mudah.

\section{Hasil Jawaban Responden tentang Siswa Memiliki Hasil Belajar Lebih Baik}

Berdasarkan data tabel 5.12 (terampir), diketahui bahwa sebanyak 14 orang atau sebesar $48,27 \%$ responden menyatakan dengan penjelasan yang disampaikan guru melalui penggunaan bahasa Lembak siswa selalu merasa hasil belajar akan lebih baik. Sebanyak 4 orang atau sebesar $13,79 \%$ responden menyatakan sering, sebanyak 8 orang atau sebesar $27,59 \%$ responden menyatakan kadang-kadang, dan sebnayak 3 orang atau $10,34 \%$ menyatakatan jarang. Sementara itu tidak terdapat siswa atau responden yang menyatakan dengan penjelasan yang disampaikan guru melalui penggunaan bahasa Lembak tidak pernah merasa hasil belajar akan lebih baik.

Sesuai dengan data table 5.13 (terlampir), diketahui bahwa sebanyak 8 orang atau sebesar $27,54 \%$ responden menyatakan dengan penjelasan yang disampaikan guru melalui penggunaan bahasa Lembak siswa selalu dapat lebih mudah mengingat materi yang diajarkan. Sebanyak 14 orang atau sebesar 48,27\% responden menyatakn sering, dan 7 orang atau sebesar $24,14 \%$ responden menyatakan kadang-kadang. Sementara itu tidak terdapat siswa atau responden yang menyatakan dengan penjelasan yang disampaikan guru melalui penggunaan bahasa Lembak siswa jarang atau tidak pernah lebih mengingat materi yang diajarkan.

Berdasarkan tabel 5.14 (terlampir), diketahui bahwa sebanyak 15 orang atau sebesar $51,72 \%$ responden menyatakan dengan penjelasana yang disampaikan guru melalui penggunaan bahasa Lembak siswa selalu dapat lebih mudah mempelajari ulang materi yang diajarkan. Sebanyak 11 orang atau sebesar 37,93\% responden menyatakan sering. Dan 3 orang atau sebesar $10,34 \%$ responden menyatakan kadang-kadang. Sementara itu tidak terdapat siswa atau responden yang menyatakan dengan penjelasan yang disampaikan guru melalui penggunaan bahasa Lembak siswa jarang ataupun tidak pernah dapat lebih mudah mempelajari ulang materi yang diajarkan.

\section{Hasil Jawaban Responden tentang Siswa Termotivasi Untuk Belajar}

Sesuai dengan data tabel 5.15 (terlampir), diketahui bahwa sebanyak 10 orang atau $34,48 \%$ respoden menyatakan dengan penjelasan yang disampaikan guru melalui penggunaan bahasa Lembak siswa selalu semangat untuk mengikuti pelajaran. Sebanyak 7 orang atau sebesar $24,14 \%$ responden menyatakan sering, sebanyak 10 orang atau sebesar $34,48 \%$ responden menyatakan kadang-kadang, dan sebanyak 2 orang atau $6,89 \%$ menyatakan jarang. Sementara itu tidak tidak terdapat siswa atau responden yang menyatakan penjelasan yang disampaikan guru dengan menggunakan bahasa Lembak tidak pernah membuat semangat untuk terus mengikuti pelajaran.

Berdasarkan data tabel 5.16 (terlampir), diketahui bahwa sebanyak 3 orang atau sebesar $10,34 \%$ responden menyatakan dengan penjelasan yang disampaikan guru melalui penggunaan bahasa Lembak siswa selalu merasa tertarik untuk menggali lebih jauh tentang mareri yang disampaikan. Sebanyak 14 orang atau sebesar $48,27 \%$ responden menyatakan sering, sebanyak 6 orang atau sebesar 20,69\% responden menyatakan jarang. Sementara itu tidak terdapat siswa atau responden yang menyatakan dengan penjelasan yang disampaikan guru melalui penggunaan bahasa Lembak tidak pernah merasa tertarik untuk menggali lebih jauh tentang materi yang disampaikan.

Sesuai dengan data tabel 5.17 (terlampir), diketahui bahwa sebanyak 13 atau sebesar $44,83 \%$ responden menyatakan dengan penjelasan yang 
disampaikan guru melalui penggunaan bahasa Lembak siswa selalu merasa pelajaran tidak membosankan. Sebanyak 4 orang atau sebesar $13,79 \%$ responden menyatakan sering, sebanyak 9 orang atau sebesar $31,03 \%$ responden menyatakan kadang-kadang, dan 3 orang atau 10,34\% menyatakan jarang. Sementara itu tidak terdapat siswa atau responden yang menyatakan melalui penggunaan bahasa Lembak siswa tidak pernah merasa pelajaran tidak membosankan.

\section{Pengujian Hipotesis dan Pembahasan}

Efektitifitas-fektifitas penggunaan bahasa Lembak kepada siswa di kelas VII SMP Negeri 1 Tanjung Terdana Bengkulu Tengah diukur melalui 5 indikator yakni tercapainya tujuan pembelajaran, materi pelajaran dapat dipahami siswa, materi dikuasai siswa, siswa memiliki hasil belajar lebih baik dan siswa termotivasi untuk beajar. Berikut adalah pembahasan masing-masing indikator tersebut sesuai dengan data hasil penelitian.

\section{Tercapainya Tujuan Pembelajaran}

Berdasarkan data tabel 5.18 (terlampir), diketahui bahwa menurut hasil penelitian bahwa dari 3 item dalam indikator tercapainya tujuan pembelajaran, penggunaan bahasa Lembak memiliki efektifitas tertinggi dalam hal tujuan pembelajaran telah tercapai dengan penjelasan guru. Sementara efektifitas terendah pada item siswa mengetahui tujuan pmbelajaran setelah mendengarkan penjelasan guru.Artinya dalam hal menyampaikan tujuan pembelajaran, penggunaan bahasa Lembak sebaiknya dikurangi.

\section{Materi Pelajaran Dapat Dipahami Siswa}

Sesuai dengan data table 5.19 (terlampir), diketahui bahwa menurut hasil penelitian bahwa dari 3 item dalam indikator materi pelajaran dapat dipahami siswa, penggunaan bahasa Lembak memiliki efektifitas tertinggi dalam hal siswa memhami isi pelajaran. Sementara efektifitas terendah pada item siswa mengetahui makna yang diajarkan setelah mendengarkan penjelasan guru.Dengan demikian dalam hal menyampaikan makna-makna dari suatu pelajaran kepada siswa, sebaiknya guru mengurangi penggunaan bahasa Lembak.

\section{Materi Dikuasai Siswa}

Berdasarkan gambaran rangkuman hasil penelitian dalam table 5.20 (terlampir), maka diketahui efektifitas tertinggi adalah pada aspek siswa merasa penguasaan bahan yang sulit menjadi lebih mudah.Sementara efektifitas terendah terjadi pada aspek siswa merasa penguasaan bahan yang sulit menjadi lebih mudah. Sementara efektifitas terendah terjadi pada aspek siswa dapat menerapkan apa yang disampaikan guru. Dengan demikian dalam penyampaian atau penjelasan tentang penerapan bahan ajar kepada siswa, sebaiknya penggunaan bahasa Lembak yang digunakan oleh guru dikurangi.

\section{Siswa Memiliki Hasil Belajar Lebih Baik}

Berdasarkan gambar rangkuman hasil penelitian dalam table 5.21 (terlampir), maka diketahui efektifitas tertinggi adalah pada aspek siswa dapat lebih mudah mempelajari ulang materi yang diajarkan. Sementara efektifitas terendah terjadi pada aspek siswa merasa hasil belajar akan lebih baik. Artinya dalam penyampaian atau penjelasan pelajaran secara umum kepada siswa, sebaiknya penggunaan bahasa Lembak yang digunakan oleh guru dikurangi.Karena siswa merasa penggunaan bahasa Lembak dianggap mempengaruhi hasil belajar siswa. 


\section{Siswa Termotivasi Untuk Belajar}

Berdasarkan gambaran rangkungam hasil penelitian dalam table 5.22 (terlampir), maka diketahui efetifitas teringgi adalah pada aspek siswa merasa pelajaran tidak membosankan.Sementara efektifitas terendah terjadi pada aspek siswa merasa tertarik untuk menggali lebih jauh tentang materi yang disampaikan.

Untuk mengetahui efektifitas penggunaan bahasa Lembak kepada siswa di kelas VII SMP Negeri 1 Tanjung Terdana Bengkulu Tengah, maka akan lihat dari rata-rata skor yang diperoleh siswa melalui penyebaran 15 item kuesioner kepada 29 siswa. Berdasarkan hasil penelitian di atas, maka diperoleh hasil skor dari 15 item pertanyaan dan 29 responden sebesar 1728. Maka rata-rata skor secara keseluruhan adalah

bahasa Lembak kepada siswa di kelas siswa di kelas VII SMP Negeri 1 Tanjung Terdana Bengkulu Tengah dapat dikatakan efektif.Dan artinya hipotesis dalam penelitian ini diterima.

Sesuai dengan hasil tersebut maka dapat dipahami bahwa penggunaan bahasa Lembak kepada siswa di kelas VII SMP Negeri 1 Tanjung Terdana Bengkulu Tengah dalam penjelasan materi pelajaran, merupakan suatu fenomena komunikasi yang terjadi di masyarakat kita. Penggunaan bahasa daerah menjadi sarana komunikasi agar dapat berjalan efektif.

Sebanyak 29 orang siswa yang diteliti di kelas VII SMP Negeri 1 Tanjung Terdana Bengkulu Tengah, sebanyak 20 orang atau sebesar $68,96 \%$ adalah siswa yang aktif menggunakan bahasa Lembak sebagai alat komunikasi sehari-hari. Dalam arti lain, mereka merupakan siswa-siswa yang berasal dari suku lembak. Sementara sebanyak 8 orang atau $31,04 \%$ adalah siswa yang tidak aktif menggunakan bahasa Lembak sebagai alat komunikasi sehari-hari. Mereka ini adalah siswa yang bukan berasal dari suku Lembak, melainkan pendatang yang berasal dari suku Jawa, Rejang dan Serawai.Pada umumnya siswa menggunakan bahasa daerah masing-masing dan bahasa Melayu Bengkulu sebagai alat komunikasinya sehari-hari.

Diketahui bahwa banyak sekali bahasa daerah digunakan sebagai bahasa berkomunikasi setiap harinya di masyarakat setempat. Hal ini dikarenakan tidak semua masyarakat memahami penggunaan bahasa Indonesia yang baku. Selain itu masyarakat merasa canggung menggunakan bahasa Indonesia yang baku di luar acara formal atau resmi. Oleh karena itu, masyarakat lebih cenderung menggunakan bahasa Indonesia yang telah terafiliasi oleh bahasa daerah, baik secara pengucapan maupun arti bahasa tersebut.

Hanya saja, kebiasan penggunaan bahasa daerah ini sedikit banyak akan berpengaruh terhadap penggunaan bahasa Indonesia yang nskrompan bällaadjkøesultasikan dengan negara Indonesia. Indonesia bukanlah bahasa ibu bagi kebanyakan penuturnya.Sebagian besar warga Indonesia menggunakan salah satu dari 784 bahasa yang ada di Indonesia sebagai bahasa ibu.Penutur Bahasa Indonesia kerap kali menggunakan versi sehari-hari (kolokial) dan/ atau mencampuradukkan dengan dialek Melayu lainnya atau bahasa ibunya. Meskipun demikian, bahasa indonesia digunakan sangat luas di perguruan-perguruan, di media massa, sastra, perangkat lunak, surat-menyurat resmi, dan berbagai forum publik lainnya, sehingga dapatlah dikatakan bahwa Bahasa Indonesia digunakan oleh semua warga Indonesia.

\section{PENUTUP \\ Kesimpulan}

Berdasarkan hasil penelitian dan pembahasan di atas, dapat diambil kesimpulan bahwa penjelasan materi pelajaran yang disampaikan guru melalui penggunaan bahasa Lembak kepada siswa di kelas VII SMP Negeri 1 Tanjung Terdana Bengkulu Tengah dapat dikatakan efektif. Hal ini berdasarkan hasil perolehan skor rata-rata sebesar 59,59 bila 
dikonsultasikan dengan skala Likert yang digunakan maka skor tersebut berada pada interval 51-62 dengan kategori efektif. Penggunaan bahasa Lembak oleh guru dalam menjelaskan materi pelajaran di kelas VII SMP Negeri 1 Tanjung Terdana Bengkulu Tengah, menurut responden dapat mempengaruhi tercapainya tujuan pembelajaran, materi pelajaran dapat dipahami siswa, materi dikuasai siswa, siswa memiliki hasil belajar lebih baik, dan siswa termotivasi untuk belajar.

\section{Saran}

Berdasarkan hasil yang ditemukan, maka kepada tenaga pengajar di SMP Negeri 1 Tanjung Terdana Bengkulu Tengah disarankan untuk terus menggunaka bahasa Lembak dan juga didukung upaya untuk meningkatkan penggunaan bahasa indonesia yang baik dan benar dalam lingkup proses belajar mengajar di sekolah. Tetapi juga untuk tetap berusaha untuk melestarikan bahasa Lembak sebagai kekayaan dari budaya masyarakat Lembak itu sendiri melalui pembinaan bahasa Lembak sebagai bahasa pergaulan di masyarakat dalam kehidupan sehari-hari.

\section{DAFTAR PUSTAKA}

Ahmad. 2011. Komunikasi Tidak Efektif. Jawa Barat. Indonesia

Liliweri, Alo. 1997. Komunikasi antarPribadi. Bandung, Citra Aditya Bakti.

Arikunto, Suharsimi. 2006. Prosedur Penelitian: Suatu Pendekatan Praktis. Jakarta, Rineka Cipta
Cangara, Hafied. 2000. Pengantar Ilmu

Komunikasi. Jakarta, Raja Grafindo Persada.

Effendi, Onong Uchana. 2005. Dinamika Komunikasi. Bandung, Remaja Rosdakarya.

Handoko, Hani T. 1997. Manajemen, Jogyakarta, Universitas Gadjah Mada Press Kurnia

Masinambow, E.K.M dan Paul Hainen. 2002. Bahasa Indonesia dan bahasa Daerah. Jakarta, Yayasan Obor Indonesia.

Mulyana, Deddy. 2005. Komunikasi Organisasi. Bandung, remaja Rosdakarya.

Nugroho, Adolf. 2012. Bahasa Indonesia Sebagai Bahasa Pengantar Dalam Proses Pendidikan di Papua. (Hasil Penelitian: Tidak Diterbitkan) (bahasa.kompasiana.com)

Pateda, Mansyur. 1987. Sosiolinguistik. Bandung, Angkasa

Purwanto, Ngalim. 2006. Evaluasi Pendidikan. Bandung, Remaja Rosdakarya.

Rohim, Syaiful. 2009. Teori Komunikasi. Rineka Cipta, Jakarta.

Sari, A.Vivi Nurinda. 2011. Pengaruh Bahasa Daerah Terhadap Pembangunan Bahasa Indonesia (Hasil Penelitian; Tidak Diterbitkan).

(bahrulfajrih.blogspot,com) Siagian, Sondang P. 1994. Filsafat Administrasi. Jakarta, Rineka Cipta 
LAMPIRAN TABEL

Tabel 5.3

Penjelasan yang Disampaikan Guru Sesuai Dengan Tujuan Pembelajaran

\begin{tabular}{|c|c|c|}
\hline Jawaban Responden & Frekuensi & Persentase \\
\hline Selalu & 13 & 44,83 \\
\hline Sering & 11 & 37,93 \\
\hline Kadang-kadang & 3 & 10,34 \\
\hline Jarang & 2 & 6,89 \\
\hline Tidak pernah & 0 & 0 \\
\hline Jumlah & 29 & $100 \%$ \\
\hline
\end{tabular}

(Sumber: Data Penelitian)

Tabel 5.4

Siswa Mengetahui Tujuan Pembelajaran Setelah Mendengarkan Penjelasan Guru

\begin{tabular}{|c|c|c|}
\hline Jawaban Responden & Frekuensi & Persentase \\
\hline Selalu & 7 & 24,14 \\
\hline Sering & 8 & 27,59 \\
\hline Kadang-kadang & 11 & 37,93 \\
\hline Jarang & 3 & 10.34 \\
\hline Tidak pernah & 0 & 0 \\
\hline Jumlah & 29 & $100 \%$ \\
\hline
\end{tabular}

(Sumber: Data Penelitian)

Tabel 5.5

Tujuan Pembelajaran Telah Tercapai Dengan Penjelasan Guru

\begin{tabular}{|c|c|c|}
\hline Jawaban Responden & Frekuensi & Persentase \\
\hline Selalu & 13 & 44,83 \\
\hline Sering & 14 & 48,27 \\
\hline Kadang-kadang & 2 & 6,89 \\
\hline Jarang & 0 & 0 \\
\hline Tidak pernah & 0 & 0 \\
\hline Jumlah & 29 & $100 \%$ \\
\hline
\end{tabular}

(Sumber: Data Penelitian)

Tabel 5.6

Siswa Memahami Isi Pembelajaran

\begin{tabular}{|l|c|c|}
\hline \multicolumn{1}{|c|}{ Jawaban Responden } & Frekuensi & Persentase \\
\hline Selalu & 7 & 24,14 \\
Sering & 17 & 58,62 \\
Kadang-kadang & 4 & 13,79 \\
Jarang & 1 & 3,45 \\
Tidak pernah & 0 & 0 \\
\hline \multicolumn{1}{|c|}{ Jumlah } & $\mathbf{2 9}$ & $\mathbf{1 0 0 \%}$ \\
\hline
\end{tabular}

(Sumber: Data Penelitian) 
Tabel 5.7

Siswa Mengetahui Makna yang Diajarkan

\begin{tabular}{|l|c|c|}
\hline \multicolumn{1}{|c|}{ Jawaban Responden } & frekuensi & Persentase \\
\hline Selalu & 9 & 31,03 \\
Sering & 17 & 24,14 \\
Kadang-kadang & 11 & 37,39 \\
Jarang & 2 & 6,89 \\
Tidak pernah & 0 & 0 \\
\hline \multicolumn{1}{|c|}{ Jumlah } & $\mathbf{2 9}$ & $\mathbf{1 0 0 \%}$ \\
\hline
\end{tabular}

(Sumber: Data Penelitian)

Tabel 5.8

Siswa Merasa Pelajaran Lebih Mudah Dipelajari

\begin{tabular}{|l|c|c|}
\hline \multicolumn{1}{|c|}{ Jawaban Responden } & Frekuensi & Persentase \\
\hline Selalu & 8 & 27,59 \\
Sering & 11 & 37,93 \\
Kadang-kadang & 10 & 34,48 \\
Jarang & 0 & 0 \\
Tidak Pernah & 0 & 0 \\
\hline \multicolumn{1}{|c|}{ Jumlah } & $\mathbf{2 9}$ & $\mathbf{1 0 0 \%}$ \\
\hline
\end{tabular}

(Sumber: Data Penelitian)

Tabel 5.10

Siswa dapat Menerapkan Apa yang Disampaikan Guru

\begin{tabular}{|l|c|c|}
\hline \multicolumn{1}{|c|}{ Jawaban Responden } & Frekuensi & Persentase \\
\hline Selalu & 6 & 20,69 \\
Sering & 15 & 51,72 \\
Kadang-kadang & 4 & 13,78 \\
Jarang & 4 & 13,78 \\
Tidak Pernah & 0 & 0 \\
\hline \multicolumn{1}{|c|}{ Jumlah } & $\mathbf{2 9}$ & $\mathbf{1 0 0 \%}$ \\
\hline
\end{tabular}

(Sumber: Data Penelitian)

Tabel 5.11

Siswa Merasa Penguasaan bahasa yang Sulit Menjadi Lebih Mudah

\begin{tabular}{|l|c|c|}
\hline \multicolumn{1}{|c|}{ Jawaban Responden } & Frekuensi & Persentase \\
\hline Selalu & 12 & 41,38 \\
Sering & 9 & 31,03 \\
Kadang-kadag & 7 & 24,14 \\
Jarang & 1 & 3,45 \\
Tidak Pernah & 0 & 0 \\
\hline \multicolumn{1}{|c|}{ Jumlah } & $\mathbf{2 9}$ & $\mathbf{1 0 0 \%}$ \\
\hline
\end{tabular}

(Sumber: Data Penelitian) 
Tabel 5.12

Siswa Merasa Hasil Belajar Akan Lebih Baik

\begin{tabular}{|l|c|c|}
\hline \multicolumn{1}{|c|}{ Jawaban Responden } & Frekuensi & Persentase \\
\hline Selalu & 14 & 48,27 \\
Sering & 4 & 13,79 \\
Kadang-kadang & 8 & 27,59 \\
Jarang & 3 & 10,34 \\
Tidak Pernah & 0 & 0 \\
\hline \multicolumn{1}{|c|}{ Jumlah } & $\mathbf{2 9}$ & $\mathbf{1 0 0 \%}$ \\
\hline
\end{tabular}

(Sumber: Data Penelitian)

Tabel 5.13

Siswa Dapat Lebih Mudah Mengingat Materi yang Diajarkan

\begin{tabular}{|l|c|c|}
\hline \multicolumn{1}{|c|}{ Jawaban Responden } & Frekuensi & Persentase \\
\hline Selalu & 8 & 27,54 \\
Sering & 14 & 48,27 \\
Kadang-kadang & 7 & 24,14 \\
Jarang & 0 & 0 \\
Tidak pernah & 0 & 0 \\
\hline \multicolumn{1}{|c|}{ Jumlah } & $\mathbf{2 9}$ & $\mathbf{1 0 0 \%}$ \\
\hline
\end{tabular}

(Sumber: Data Penelitian)

Tabel 5.14

Siswa dapat Lebih Mudah Mempelajari Ulang Materi yang Diajarkan

\begin{tabular}{|l|c|c|}
\hline \multicolumn{1}{|c|}{ Jawaban Responden } & Frekuensi & Persentase \\
\hline Selalu & 15 & 51,72 \\
Sering & 11 & 39,93 \\
Kadang-kadang & 3 & 10,34 \\
Jarang & 0 & 0 \\
Tidak pernah & 0 & 0 \\
\hline \multicolumn{1}{|c|}{ Jumlah } & $\mathbf{2 9}$ & $\mathbf{1 0 0 \%}$ \\
\hline
\end{tabular}

(Sumber: Data Penelitian)

Tabel 5.15

Siswa Semangat Untuk Terus Mengikuti Pelajaran

\begin{tabular}{|l|c|c|}
\hline \multicolumn{1}{|c|}{ Jawaban Responden } & Frekuensi & Persentase \\
\hline Selalu & 10 & 34,48 \\
Sering & 7 & 24,14 \\
Kadang-kadang & 10 & 34,48 \\
Jarang & 2 & 6,89 \\
Tidak Pernah & 0 & 0 \\
\hline \multicolumn{1}{|c|}{ Jumlah } & $\mathbf{2 9}$ & $\mathbf{1 0 0 \%}$ \\
\hline
\end{tabular}

(Sumber: Data Penelitian) 
Tabel 5.16

Siswa Merasa Tertarik untuk Menggali Lebih Jauh Tentang

Materi Yang Disampaikan

\begin{tabular}{|l|c|c|}
\hline \multicolumn{1}{|c|}{ Jawaban Responden } & Frekuensi & Persentase \\
\hline Selalu & 3 & 10,34 \\
Sering & 14 & 48,27 \\
Kadang-kadang & 6 & 20,69 \\
Jarang & 6 & 20,69 \\
Tidak Pernah & 0 & 0 \\
\hline \multicolumn{1}{|c|}{ Jumlah } & $\mathbf{2 9}$ & $\mathbf{1 0 0 \%}$ \\
\hline
\end{tabular}

(Sumber: Data Penelitian)

Tabel 5.17

Siswa Merasa Pelajaran Tidak Membosankan

\begin{tabular}{|l|c|c|}
\hline \multicolumn{1}{|c|}{ Jawaban Responden } & Frekuensi & Persentase \\
\hline Selalu & 13 & 44,83 \\
Sering & 4 & 13,79 \\
Kadang-kadang & 9 & 31,03 \\
Jarang & 3 & 10,34 \\
Tidak Pernah & 0 & 0 \\
\hline \multicolumn{1}{|c|}{ Jumlah } & $\mathbf{2 9}$ & $\mathbf{1 0 0 \%}$ \\
\hline
\end{tabular}

(Sumber: Data Penelitian)

Tabel 5.18

Tercapainya Tujuan Pembelajaran

\begin{tabular}{|l|l|c|}
\hline No. & \multicolumn{1}{|c|}{ Item Pertanyaan } & Skor \\
\hline 1. & $\begin{array}{l}\text { Penjelasan Yang Disampaikan Guru Sesuai } \\
\text { Dengan Tujuan Pembelajaran }\end{array}$ & 122 \\
\hline 2. & $\begin{array}{l}\text { Siswa Mengetahui Tujuan Pembelajaran Setelah } \\
\text { Mendengarkan Penjelasan Guru }\end{array}$ & 127 \\
\hline 3. & $\begin{array}{l}\text { Tujuan Pembelajaran Telah Telah Tercapai } \\
\text { Dengan Penjelasan Guru }\end{array}$ \\
\hline
\end{tabular}

Tabel 5.19

Materi Pelajaran Dapat Dipahami Siswa

\begin{tabular}{|l|l|c|}
\hline No. & \multicolumn{1}{|c|}{ Item Pertanyaan } & Skor \\
\hline 1. & Siswa Memahami Isi Pelajaran & 117 \\
\hline 2. & Siswa Mengetahui Makna Yang Diajarkan & 110 \\
\hline 3. & Siswa Merasa Pelajaran Lebih Mudah Dipelajari & 114 \\
\hline
\end{tabular}


Tabel 5.20 Materi Dikuasai Siswa

\begin{tabular}{|l|l|c|}
\hline No. & \multicolumn{1}{|c|}{ Item Pertanyaan } & Skor \\
\hline 1. & Siswa dapat Menguasai Materi yang Diajarkan & 115 \\
\hline 2. & $\begin{array}{l}\text { Siswa dapat Menerapkan Apa yang Disampaikan } \\
\text { Guru }\end{array}$ & 110 \\
\hline 3. & $\begin{array}{l}\text { Siswa Merasa Penguasaan Bahan yang Sulit } \\
\text { Menjadi Lebih Mudah }\end{array}$ \\
\hline
\end{tabular}

Tabel 5.21 Siswa Memiliki Hasil Belajar Lebih Baik

\begin{tabular}{|l|l|c|}
\hline No. & \multicolumn{1}{|c|}{ Item Pertanyaan } & Skor \\
\hline 1. & Siswa Merasa Hasil Belajar Akan Lebih Baik & 116 \\
\hline 2. & $\begin{array}{l}\text { Siswa Dapat Lebih Mudah Mengingat Materi yang } \\
\text { Diajarkan }\end{array}$ & 117 \\
\hline 3. & $\begin{array}{l}\text { Siswa dapat Lebih Mudah Mempelajari Ulang } \\
\text { Materi yang Diajarkan }\end{array}$ & 128 \\
\hline
\end{tabular}

Tabel 5.22 Motivasi Siswa Untuk Belajar

\begin{tabular}{|l|l|c|}
\hline No. & \multicolumn{1}{|c|}{ Item Pertanyaan } & Skor \\
\hline 1. & Siswa Semangat Untuk Terus Mengikuti Pelajaran & 112 \\
\hline 2. & $\begin{array}{l}\text { Siswa Merasa Tertarik untuk Menggali Lebih Jauh } \\
\text { tentang Materi yang Disampaikan }\end{array}$ & 101 \\
\hline 3. & Berdasarkan Pelajaran Tidak Membosankan & 114 \\
\hline
\end{tabular}

